\title{
PERPINDAHAN PEMUKIMAN MASYARAKAT BAJO DARI PULAU MASUDU SULAWESI TENGGARA (Moving of Bajo Community Settlement From Masudu Island, South East Sulawesi)
}

\author{
Simon Sirua Sarapang \\ Balai Pelestarian Nilai Budaya Sulawesi Selatan \\ Jalan Sultan Alauddin / Tala Salapang Km. 7 Makassar, 90221 \\ Telepon (0411) 865166 Faksimile (0411) 865166 \\ e-mail: rismawidiawati@yahoo.com
}

INFO ARTIKEL

\section{Histori Artikel}

Diterima: 5 Maret 2018

Direvisi: 3 April 2018

Disetujui: 4 Juni 2018

\section{Keywords}

Liano Village

Bajo Community

Settlement pattern

\section{Kata Kunci \\ Desa Liano \\ Masyarakat Bajo \\ Pola pemukiman}

\section{ABSTRACT}

The movement of people from one area to another can improve the structure of community settlements and socio-economic structures. This paper aims to determine the background of the settlement of the Bajo people from Masudu Island to the coast of Liano Village, the process of relocating the Bajo Community from Masudu Island to the coast of Liano Village, the settlement pattern of the Bajo Community, the socio-economic life of the Bajo community. Data collection consists of three types of study documents, interviews, and observations. The collected data is verified by two stages, namely: verification of internal data, and verification of external data. The next stage is the stage of interpretation which consists of analysis and synthesis. The results showed that the background of the movement of the Bajo people in Liano Village was a factor in the damage to houses due to strong winds and tides, the government policy of inadequate Bajo community income. The process of moving the Bajo community was carried out in stages, starting with the people who lived in the western part of Masudu Island in 1999, by crossing the sea and some people carrying home tools on Masudu Island. The pattern of settlement of Bajo people in the neighborhood Liano village is linearly following the highway with the distance between houses close together. The socio-economic life of the Bajo community in Liano Village is the creation of interactions with other communities on the land and the availability of infrastructure for the Bajo people so that they facilitate activities.

\section{ABSTRAK}

Perpindahan penduduk dari satu daerah ke daerah lainnya dapat memperbaiki struktur pemukiman masyarakat dan struktur sosial ekonomi. Tulisan ini bertujuan untuk mengetahui latarbelakang perpindahan pemukiman Masyarakat Bajo dari Pulau Masudu ke pesisir pantai Desa Liano, proses perpindahan pemukiman Masyarakat Bajo dari Pulau Masudu ke pesisir pantai Desa Liano, pola pemukiman Masyarakat Bajo, kehidupan sosial ekonomi masyarakat Bajo. Pengumpulan data terdiri dari tiga jenis yaitustudi dokumen, wawancara, dan observasi. Data yang telah dikumpulkan tersebut dilakukan verifikasi yang terdiri dari dua tahap yakni: verifikasi data internal, dan verifikasi data eksternal. Tahapan selanjutnya adalah tahap interpretasi yang terdiri dari analisis dan sintesis. Hasil penelitian menunjukan bahwa latar belakang perpindahan masyarakat Bajo di Desa Liano adalah faktor kerusakan rumah akibat angin kencang dan pasang air laut, kebijakan pemerintah penghasilan masyarakat bajo yang kurang mencukupi. Proses perpindahan masyarakat Bajo dilakukan secara bertahap yang diawali masyarakat yang tinggal di bagian Barat Pulau Masudu pada tahun 1999, dengan menyebrangi laut dan sebagian masyarakat membawa perkakas rumah yang ada di Pulau Masudu. Pola pemukiman masyarakat Bajo di Lingkungan Desa Liano berbentuk linear mengikuti jalan raya dengan jarak antara rumah saling berdekatan. Kehidupan sosial ekonomi masyarakat Bajo di Desa Liano adalah terciptanya interaksi dengan masyarakat lain yang ada di darat serta tersedianya prasarana bagi masyarakat Bajo sehingga mempermudah mereka dalam berbagai aktivitas. 


\section{PENDAHULUAN}

Perpindahan penduduk dari satu daerah ke daerah lainnya merupakan masalah yang tidak ada habisnya. Sebagaimana kita ketahui bahwa penduduk Indonesia yang heterogen, dan terdiri dari berbagai macam suku bangsa yang tersebar di seluruh pelosok tanah air, yang merupakan wujud nyata dari makna Bhinneka Tunggal Ika. Dengan keragaman suku bangsa (ras), bahasa, agama, budaya, dan adat istiadat yang tersebar dan menempati wilayah di antara pulau dan kepulauan Nusantara dari Sabang sampai Merauke. Di mana hal tersebut merupakan dinamika penduduk yang senantiasa terdapat pada setiap bangsa atau Negara berlangsung dari waktu ke waktu bahkan dalam tiap harinya dapat kita amati orang yang melakukan perpindahan baik melalui angkutan darat, laut maupun udara.

Pemukiman merupakan tempat tinggal dan tempat melakukan kegiatan untuk mendukung kehidupan penghuninya, yaitu hubungan antara manusia dengan manusia, dengan alam serta dengan pencipta-Nya Apabila diamati, hubungan itu mempunyai pola yang sesuai dengan kekuatan non fisik yang tumbuh pada masyarakatnya. Oleh karena itu pemukiman merupakan cerminan dari pengaruh sosial budaya masyarakat.

Pemukiman secara fisik tidak terbatas pada tempat tinggal saja, tetapi merupakan satu kesatuan sarana dan prasarana lingkungan terstruktur. Hubungan ini saling mempengaruhi dan dipengaruhi secara terus menerus dari waktu ke waktu, sehingga terdapat petunjuk dan aturan tentang penataan lingkungan pemukiman. Oleh sebab itu, kegiatan manusia pada lingkungan permukiman mempunyai pola-pola yang mengatur dan menjaga keseimbangan alam.

Apabila dicermati, pemukiman memiliki bentuk tersendiri sesuai dengan kekuatan non fisik yang tumbuh pada masyarakat, berupa sistem sosial budaya, pemerintahan, tingkat pendidikan, serta teknologi terapan yang kesemuanya akan membawa perubahan kepada ungkapan fisik lingkungannya. Salah satu faktor yang sangat berpengaruh adalah sistem sosial budaya.

Batubara Dalam Blaang (1986: 78) merumuskan bahwa permukiman adalah suatu kawasan perumahan yang ditata secara fungsional, ekonomi dan fisik tata ruang yang dilengkapi dengan prasarana lingkungan, sarana secara umum dan fasilitas sosial sebagai suatu kesatuan yang utuh dengan membudidayakan sumber daya dan dana, mengelola lingkungan yang ada untuk mendukung kelangsungan peningkatan mutu kehidupan manusia, memberi rasa aman, tentram dan nikmat, nyaman dan sejahtera dalam keserasian dan keseimbangan agar berfungsi sebagai wadah yang dapat melayani kehidupan pribadi, keluarga, masyarakat, bangsa dan negara. Permukiman merupakan suatu lingkungan hidup yang 
berada diluar kawasan lindung baik yang berupa kawasan perkotaan maupun perdesaan yang berfungsi sebagai lingkungan tempat tinggal serta tempat kegiatan usaha dan kerja yang mendukung kehidupan dan penghidupan. Hal inilah yang menjadikan pada tingkat primer permukiman tempat tinggal. Pada tingkat lebih lanjut, permukiman dapat diberi fungsi atau misi sebagai penyangga kawasan fungsional serta kawasan produktif lainnya.

Proses perpindahan penduduk ternyata dapat berpengaruh sangat luas dan turut mempengaruhi pembangunan nasional, karena dapat memperbaiki struktur pemukiman masyarakat dan struktur sosial ekonomi. Dalam hal ini proses perpindahan penduduk dari suatu wilayah sampai bermukim di wilayah lainnya adalah suatu gerak sejarah yang sangat menarik untuk dikaji dan diteliti secara mendalam, karena di dalamnya mengandung beberapa nilai yang dapat menambah pengetahuan kita mengenai suatu peristiwa sejarah.

Pesisir merupakan wilayah yang sangat berarti bagi kehidupan manusia di bumi. Sebagai wilayah peralihan darat dan laut yang memiliki keunikan ekosistem, dunia memiliki kepedulian terhadap wilayah ini, khususnya di bidang lingkungan dalam konteks pembangunan berkelanjutan (sustainable development). Secara historis, kota- kota penting dunia bertempat tidak jauh dari laut. Alasannya, kawasan ini memiliki potensi sumber daya kelautan dan perikanan, serta memudahkan terjadinya perdagangan antar daerah, pulau dan benua.

Perkembangan masyarakat Bajo sampai saat ini sudah banyak tinggal di wilayah Pesisir dengan mendirikan rumah serta membentuk pemukiman, pada zaman dahulu masyarakat Bajo masih bertahan hidup di dalam perahu bido (leppa). Namun sekarang ini, leppa sebagai tempat tinggal masyarakat Bajo tidak lagi diperbolehkan tinggal di perahu yang ukurannya sangat kecil, hal ini untuk mencegah jatuhnya korban jiwa. Leppa hanya digunakan oleh para nelayan untuk menetap beberapa saat dalam proses penagkapan ikan (Nasruadin, 2004: 40). Ini terlihat pada masyarakat Bajo di Desa Liano Kecamatan Mataoleo. Kabupaten Bombana.

Masyarakat Bajo yang berada di Pulau Masudu mulai berpindah ke darat secara berangsur-angsur sejak tahun 1999 disebabkan oleh beberapa faktor di antaranya adalah factor kerusakan dan faktor ekonomi masyarakat Bajo di darat mulai membuka usaha seperti berwiraswasta, juga sebahagian besar masih menggantungkan kehidupannya di laut dengan berprofesi sebagai nelayan.

Untuk menguraikan perpindahan pemukiman masyarakat Bajo dari pulau masudu ke pesisir pantai Desa Liano Kecamatan Mataoleo Kabupaten Bombana dilakukan penelitian dengan mempelajari gejala-gejala maupun kenyataan- kenyataan 
yang ada pada masyarakat Pulau Masudu. Berdasarkan latar penelitian di atas, maka dirumuskan pertanyaan penelitian sebagai berikut:

1. Apa yang melatarbelakangi perpindahan pemukiman Masyarakat Bajo dari Pulau Masudu ke pesisir pantai Desa Liano Kecamatan Mataoleo Kabupaten Bombana?

2. Bagaimana proses perpindahan pemukiman Masyarakat Bajo dari Pulau Masudu ke pesisir pantai Desa Liano Kecamatan Mataoleo Kabupaten Bombana?

3. Bagaimana pola pemukiman Masyarakat Bajo di pesisir pantai Desa Liano Kecamatan Mataoleo Kabupaten Bombana?

4. Bagaimana kehidupan sosial ekonomi Masyarakat Bajo di Pesisir Pantai Desa Liano Kecamatan Mataoleo Kabupaten Bombana?

Sebelum penulis melakukan penelitian terhadap judul "Perpindahan Pemukiman Masyarakat Bajo dari Pulau Masudu ke Pesisir Pantai Desa Liano Kecamatan Mataoleo Kabupaten Bombana tahun 1999-2014", telah dilakukan penelitian sebelumnya tentang Perpindahan (Migrasi) dari beberapa daerah di Sulawesi Tenggara.

Penelitian ini mengacu pada penelitian yang pernah dilakukan tetapi dari sudut kajian memiliki perbedaan pandangan serta lokasi penelitian yang berbeda seperti penelitian yang dilakukan oleh Jarmasi (1996) tentang "Migrasi Orang Bajo di Desa Waitii Kecamatan Tomia". Dari kesimpulan yang diambil dari hasil penelitian yang dilakukannya bahwa proses kedatangan Orang Bajo di Desa Waitii terjadi melalui tiga Fase dan dilakukan secara berantai oleh mereka yang masih ada hubungan keluarga. Motif perpindahan Orang-orang Bajo di Desa Waitii ditinjau dari faktor-faktor pendorong daerah asal berupa kesempatan ekonomi, tradisi, demografi, sosial, dan faktor penarik daerah tujuan adalah geografis, sumber daya alam daerah tujuan, letak yang strategis dan keterbukaan pemerintah dalam menerima arus migrasi dalam hal ini perpindahan.

Penelitian selanjutnya dilakukan oleh Jumardi (2014) dengan judul Dari Laut Ke darat: Pola Pemukiman Masyarakat Bajo di Kelurahan Boepinang Kecamatan Poleang Kabupaten Bombana. Penelitian ini berkesimpulan bahwa yang melatar belakangi suku Bajo di kelurahan Boepinang melakukan perpindahan ke darat disebabkan karena adanya perubahan pola pikir dari masyarakat Bajo itu sendiri. disamping itu juga disebabkan oleh beberapa faktor lain seperti Faktor pendidikan, faktor kerjasama pemerintah, faktor geografis, faktor ekonomi dan faktor kerusakan.

Selain penelitian diatas, masih banyak penelitian yang sejenis yang penulis tidak uraikan dalam hasil penelitian ini, namun dari hasil penelitian tersebut belum ada satu 
penelitian pun yang memfokuskan kajiannya pada "Perpindahan Pemukiman Masyarakat Bajo dari Pulau Masudu ke Pesisir Pantai Desa Liano Kecamatan Mataoleo Kabupaten Bombana tahun 1999-2014".

\section{METODE}

Penelitian ini menggunakan pendekatan strukturis yaitu mempelajari peristiwa dan struktur sebagai satu kesatuan yang saling melengkapi. Artinya peristiwa mengandung kekuatan mengubah struktur sosial, sedangkan struktur mengandung hambatan atau dorongan bagi tindakan perubahan dalam masyarakat. Dalam hal ini adalah dorongan tindakan bagi masyarakat Bajo untuk membentuk pemukiman di darat.

Dalam penelitian ini, penulis menggunakan dua kategori sumber data penelitian yaitu sebagai berikut:

1. Sumber tertulis, yaitu data yang diperoleh dari berbagai literatur dalam bentuk buku dan skripsi, laporan hasil penelitian serta sumber tertulis lainnya yang sesuai dengan kajian penelitian ini.

2. Sumber lisan, yaitu tindakan pengambilan data yang diperoleh dari hasil wawancara dengan para informan, diantaranya adalah tokoh masyarakat, tokoh agama, pemerintah setempat yang mengetahui tentang permasalahan yang diteliti, suatu pengamatan beberapa kegiatan ke masyarakat yang terekam ketika melakukan penelitian.

3. Sumber visual, yaitu data yang diperoleh dari hasil pengamatan mengenai beberapa bentuk kegiatan berupa, kegiatan kemasyarakatan, upacara adat, kesenian dan sopan santun dalam pergaulan yang berkaitan dengan wujud kearifan lokal.

Jejak-jejak diri dari pada sejarah sebagai peristiwa, merupakan sumbersumber bagi sejarah sebagai kisah dan disebut heuristic yang berasal dari bahasa Yunani Heuriskein berarti menemukan (Nugroho Notosusanto, 1978: 36).

Heuristik merupakan salah satu tahap awal dalam penelitian sejarah, yaitu proses mencari, menemukan dan mengumpulkan data-data atau sumber-sumber sejarah yang dianggap sesuai dengan fokus kajian. Teknik pengumpulan data dalam penelitian ini adalah sebagai berikut:

1. Pengamatan (Observasi), yaitu aktivitas dalam koleksi data dengan cara mengamati dan mencatat mengenai kondisi objek penelitian.

2. Wawancara (interview), yaitu melakukan Tanya jawab dengan para informan yang banyak memiliki pemahaman dan pengetahuan perpindahan pemukiman masyarakat Bajo ke Pesisir Pantai Desa Liano. 
Tahap selanjutnya kritik sumber (verifikasi data) dan pada tahap ini, penulis melakukan penelitian terhadap sumber data yang telah terkumpul, khususnya data yang masih diragukan otentitas dan kredibilitasnya. Untuk mengetahui otentitas (keaslian) dan kredibilitas (kebenaran) data yang telah terkumpul tersebut maka peneliti melakukan analisis kritik sejarah, baik kritik eksternal maupun kritik internal.

Setelah melakukan penilaian data melalui kritik ekstern dan kritik intern, maka data tersebut di Interpretasi atau ditafsirkan dengan mengacu pada konsep yang berhubungan dengan masalah yang diteliti. Pada bagian interpretasi ini otentitas dan kredibilitas sumber data yang sudah ditetapkan melalui kritik selanjutnya dihubungkan antara data yang satu dengan yang lainnya sehingga didapatkan fakta sejarah yang dapat dipercaya kebenarannya secara ilmiah yang dapat dilakukan dengan cara sebagai berikut:

1. Analisis yaitu proses menguraikan sumber-sumber data, karena kadangkadang sebuah sumber mengandung beberapa kemungkinan, mana sumber yang asli dan bukan.

2. Sintesis yaitu proses menyatukan berapa data yang terkumpul yang dianggap saling berhubungan dan relevan dengan penelitian yang dikaji.
Historiografi atau penyusunan data merupakan bagian akhir dari seluruh rangkaian penelitian sejarah. Pada bagian ini penulis menyusun kisah secara kronologis dan sistematis berdasarkan data dan fakta yang berhasil dikumpulkan dan telah lulus verifikasi serta Sudan diinterpretasikan.

\section{PEMBAHASAN}

Awal kedatangan masyarakat Bajo di Pulau Masudu belum memiliki pemukiman yang menetap, mereka selalu berpindahpindah dari satu tempat ketempat yang lain. Kegiatan ini dilakukan untuk memenuhi kebutuhan hidupnya. Aktifitas tersebut membuat masyarakat Bajo sangat tergantung pada keadaan alam yang berada di laut, kebiasaan berpindah-pindah dari satu tempat ketempat yang lain sudah menjadi tradisi masyarakat Bajo karena mereka memandang kebiasaan berpindah-pindah untuk menambah penghasilannya. Seiring dengan perkembangan zaman, masyarakat Bajo mengalami perubahan kebiasaan, dari kebiasaan berpindah-pindah menjadi pemukiman menetap di atas permukaan air laut dengan mendirikan ruma'n panggung.

Hasil penelitian menunjukkan bahwa latar belakang perpindahan masyarakat Bajo dari Pulau Masudu ke Pesisir pantai Desa Liano disebabkan karena adanya kemauan dari masyarakat Bajo itu sendiri, disamping 
itu juga disebabkan oleh beberapa faktor lain seperti:

\section{Faktor Geografi}

Menurut penuturan informan bahwa salah satu faktor perpindahan masyarakat Bajo dari Pulau Masudu ke pesisir Pantai Desa Liano Kecamatan Mataoleo Kabupaten Bombana adalah faktor geografi dimana pada musim Barat masyarakat yang bermukim di wilayah Barat Pulau tersebut. Mereka ngotot melakukan perpindahan, karena rumah yang dihuni selama ini sering menjadi sasaran bencana Rob (pasang air laut) serta angin kencang sehingga masyarakat Pulau Masudu di relokasi ke Desa Liano Kecamalan Malaoleo (Syarifuddin, wawancara, 21 Juni 2015).

Berdasarkan penuturan informan tersebut perpindahan masyarakat Bajo di Pesisir Pantai Desa Liano diakibatkan oleh kondisi alam tempat tinggal mereka yang tidak menentu dan bahkan tidak jarang jika paua musim-musim tertentu dapat mengancam keselamatan masyarakat setempat. Selain itu, penghasilan yang kurang mencukupi kehidupan mereka seharihari dapat menunjang pergesaran tempat masyarakat Bajo dari Pulau Masudu sampai ke Desa Liano. Hasil penelitian di lapangan menunjukkan, bahwa faktor pendukung lain terjadinya perpindahan tersebut karena kelembaban air laut, arus yang begitu besar serta keadaan cuaca di laut yang tidak menentu dapat membuat tempat tinggal mereka terancam yang dimulai dari tiang bangunan rumah yang mulai lapuk karena selalu terendam oleh air laut dalam waktu yang sangat lama sehingga tiang tersebut mulai rusak dan menjadi ancaman bagi masyarakat yang ada disekitarnya.

Pola ruang pemukiman masyarakat Bajo pada prinsipnya terbentuk karena adanya pergeseran pola tempat tinggal yang tidak terlepas dari berbagai faktor yang mempengaruhinya. Walaupun demikian tidak serta merta masyarakat Bajo yang telah bermukim di Desa Liano meninggalkan mata pencaharian pokok mereka sebagai nelayan, akan tetapi mereka tetap melakukan pekerjaan sebagai nelayan untuk menambah dan mengoptimalkan penghasilan mereka. Setelah masyarakat menetap di Desa Liano kehidupan sudah lebih baik sebab penangkapan ikan sampai pemasarannya lebih optimal dibandingkan sejak mereka masih bermukim di Pulau. Hal tersebut ditunjang oleh sarana dan prasarana di daral yang mendukung seperti hasil tangkapan masyarakat nelayan dapat disimpan di tempat pendingin sebelum hasil tangkapan tersebut lapuk (Myusuf. Wawancara, 23 Juni 2015).

Dari penjelasan diatas terlihat bahwa keberadaan masyarakat Bajo sebelum berada di Desa Liano mengalami berbagai masalah terutama dalam pemasaran ikan dan kebutuhan pendingin untuk mengawetkan ikan agar tetap segar, namun semua itu dapat 
diatasi setelah mereka bermukim di darat kebutuhan itu hampir terpenuhi dan bahkan mereka dapat menjual ikannya langsung ke konsumen.

Seiring dengan perjalanan waktu perkembangan pemukiman terjadi karena faktor alam, dekat dengan transportasi, pertambahan penduduk, ekonomi, dan sosial.

Bagi kasus pemukiman masyarakat Bajo di lingkungan Bajo Desa Liano disebabkan oleh pesatnya perkembangan penduduk dari masyarakat. Hal ini dikarenakan masyarakat Bajo telah membaur dengan masyarakat di Desa Liano khususnya masyarakat Bugis dan masyarakat lainnya, seperti pembauran dari perkawinan mereka telah menikah dengan masyarakat yang bermukim di Desa Liano dan lebih memilih untuk bermukim di Desa Liano sehingga pemukiman ini menjadi pusat pemukiman masyarakat Bajo sejak perpindahan mereka pada tahun 1999 sampai sekarang.

\section{Faktor Kebijakan Pemerintah}

Seiring dengan perkembangan zaman masyarakat Bajo sebagian sudah mendapatkan pendidikan formal. Dengan adanya kerjasama maupun dukungan pemerintah Kabupaten Bombana sangat mendukung perpindahan pemukiman masyarakat Bajo ke Daral yakni Desa Liano. Menurut penuturan informal, perpindahan pemukiman masyarakat Bajo dari Pulau Masudu ke Desa Liano tidak terlepas dari kerjasama atau dukungan pemerintah setempat yang memberikan kemudahan kepada masyarakat Bajo dalam memenuhi kebutuhan lahan pemukiman, rumah, air bersih maupun kebutuhan lain, yang dibutuhkan oleh masyarakat Bajo (Syarifuddin, Wawancara, 23 Juni 2015).

Menurut penuturan informan lagi bahwa kebijakan pemerintah merupakan salah satu faktor mengenai perpindahan pemukiman masyarakat Bajo dari Pulau Masudu ke Pesisir Pantai Desa Liano yang prihatin akan keselamatan masyarakatnya yang tinggal di Pulau kecil yang sewaktuwaktu dapat diterka angin kencang dan bencana rob yakni pasang air laut (Myusuf, Wawancara, 23 Juni 2015).

\section{Faktor Ekonomi}

Penghasilan masyarakat Bajo yang tidak menentu menjadi salah satu faktor perpindahan masyarakat Bajo dari Pulau Masudu ke Desa Liano sebab penghasilan mereka yang kurang mencukupi dalam kebutuhan sehari-hari. Menurut Myusuf pada waktu masyarakat tinggal di Pulau Masudu mata pencaharian masyarakat mayoritas sebagai nelayan setelah pindah di Desa Liano Masyarakat mulai membuka waning, pangkalan minyak tanah, dan kios-kios kecil sebagai tempat jualan. Sebagai contoh masyarakat Bajo yang sudah pindahan ke Desa Liano, mereka menjual bahan sembako, 
makanan ringan, bahan bakar, dan lain- lain (Myusuf, Wawancara, 9 Juni 2015).

\section{Proses Perpindahan Masyarakat Bajo}

Manusia merupakan makhluk yang dinamis yang telah bergerak dari satu tempat ke tempat yang lain. Hal ini merupakan keniscayaan sebab salah satu cirri dari makhluk hidup adalah bergerak. Bergeraknya suatu manusia dari tempat yang satu ke tempat yang lain disebabkan oleh beberapa faktor, baik itu faktor yang berasal dalam diri manusia itu ataupun factor yang dating dari luar masyarakat.

Sejarah mengungkapkan bahwa setelah adanya program dari pemerintah pada tahun 1999 telah membuka lembaran baru bagi perpindahan masyarakat Bajo di Desa Liano, sebab masyarakat Bajo sekarang telah menempati pemukiman baru yang dikenal dengan nama Polewali.

Perpindahan yang dilakukan masyarakat Bajo dilakukan atas dasar usulan pemerintah setempat. Pemerintah melihat bahwa masyarakat Bajo yang tinggal di Pulau Masudu mengalami kesulitan baik dari segi pemukiman maupun dari segi kebutuhan hidup. Ditambah lagi tujuan dari pemindahan ialah untuk memberikan pelayanan kepada masyarakat dan upaya untuk meningkatkan taraf hidup masyarakat.

Mendengar rencana dari pemerintah setempat pada awalnya masyarakat tidak merespon dengan baik usulan pemerintah tersebut, hal ini dikarenakan masyarakat Bajo yang tinggal di bagian Timur Pulau Masudu merasa aman dengan hidup mereka disisi lain masyarakat yang tinggal di bagian barat pulau tersebut ngotot pindah karena rumah yang dihuninya selalu terkena sasaran bencana rob (pasang air laut).

Respon yang kurang baik dari masyarakat Bajo membuat pemerintah melakukan berbagai cara dengan menyebarkan isu bahwa Pulau Masudu yang merupakan tempat mereka tinggal akan dijadikan sebagai tempat wisata oleh orang Barat, tetapi hal ini masih belum pasti sebab sebagian narasumber membenarkan bahwa pulau tersebut akan dijadikan sebagai tempat wisata dan sebagian lain menyanggah pendapat ini dan menyatakan itu hanya sekedar isu dengan tujuan masyarakat menerima usulan pemerintah untuk pindah.

Mendengar pernyataan pemerintah bahwa kelangsungan hidup mereka terancam maka saat itu muncul kecemasan dalam diri mereka dan mulai ada keinginan masyarakat Bajo untuk pindah. Keinginan dari masyarakat untuk pindah rupanya terbentur masalah lokasi tempat mereka nantinya sehingga masyarakat menjadi bingung. Akhirnya angin segar pun datang menghembus masyarakat Bajo bagaimana tidak di tengah kerisauan masyarakat muncul pernyataan dari pemerintah bahwa telah ada lokasi yang diperuntukkan bagi mereka untuk 
pindah dan menetap. Menurut Nurung sebenarnya ketika kami mendengar adanya isu tentang pulau masudu akan dijadikan tempat wisata saat itu mulai ada keinginan dari sebagian masyarakat untuk pindah ke Desa Liano telapi kami tidak tahu akan pindah dimana, akhirnya kami mendengar bahwa ada lokasi yang lelah disediakan pemerintah (wawancara Nurung, 21 Juni 2015).

Pemerintah menyediakan sarana untuk perpindahan yaitu lahan atau tanah untuk masyarakat bermukim, setelah masyarakat mendapat lokasi yang cocok mulailah membangun pemukiman baru mereka dengan permulaan mereka membersihkan tempat tersebut yang saat itu masih hutan kemudian barulah masyarakat secara bergotong-royong membangun perumahan mereka dan sebagian masyarakat menempati rumah yang disediakan oleh pemerintah.

Proses perpindahan masyarakat Bajo dilakukan secara bertahap yang diawali masyarakat yang tinggal di bagian Barat Pulau Masudu pada tahun 1999, masyarakat Bajo yang tinggal di bagian Barat Pulau Masudu adalah masyarakat yang pertama kali memutuskan pindah ke pemukiman baru yang jumlah 103 kepala keluarga dan sekarang menempati pemukiman Blok B, kemudian menyusul masyarakat Iain mengikutinya untuk pindah yang berjumlah
142 kepala keluarga dan sekarang menempati pemukiman Blok A.

Masyarakat Bajo dalam proses perpindahannya ialah dengan menyeberangi laut yang jarak antara pemukiman lama dengan pemukiman baru sekitar $5 \mathrm{~km}$ dengan menggunakan perahu yang ditempuh kurang lebih selama 45 menit, saat perpindahan sebagian masyarakat Bajo membawa perkakas rumah mereka, sehingga mereka haus ekstra hati-hati sebab perahu yang digunakan tidak cukup besar untuk memuat perkakas rumah yang banyak dan berat (wawancara, Nurung, 21 Juli 2015).

Perpindahan terakhir yang dilakukan oleh masyarakat Bajo terjadi pada tahun 2013 yang dilakukan oleh sebagian masyarakat yang bermukim di wilayah timur pulau Masudu, perpindahan ini disebabkan sudah semakin sedikitnya masyarakat yang bermukim di Pulau Masudu selain itu adanya desakan dari sanak saudara yang telah menetap di pemukiman baru yakni Desa Liano, perpindahan masyarakat Bajo pada tahap ini berjumlah 81 kepala keluarga dan sekarang menempati pemukiman Blok C, dan 35 kepala keluarga menempati pemukiman Blok D.

Pola Pemukiman Masyarakat Bajo di Pesisir Pantai Desa Liano

Pemukiman masyarakat Bajo yang berada di Pesisir Pantai Desa Liano memiliki luas wilayah 11 Ha yang membujur dari arah 
utara ke arah barat dengan menghadap ke jalan dan posisi rumah saling berhadapan dan berdempetan yang terletak di wilayah pesisir atau dengan kata Iain berada dekat dengan pantai (Myusuf, Wawancara, 23 Juni 2015).

Dari luas wilayah tersebut $9 \mathrm{Ha}$ digunakan untuk pemukiman dan sisanya yakni 2 Ha digunakan sebagai lahan pekarangan. Disamping itu Masyarakat Bajo memanfaatkan pekarangan mereka sebagai tempat jualan dan juga tempat berinteraksi anak-anak serta beraktivitas lainnya. Pemukiman masyarakat Bajo di darat yakni Desa Liano berjejer dan menghadap ke jalan. Selain itu, masyarakat ketika bermukim di darat membangun tempat tinggal secara berkelompok, rial ini didasarkan kuatnya rasa persaudaraan dan kemudahan-kemudahan lainnya.

Setelah perpindahan masyarakat Bajo terjadi perubahan pola pemukiman dimana saat ini pola pemukiman masyarakat Bajo berbentuk linear yang mengikuti jalan raya. Hal ini dapat diketahui berdasarkan pengamatan lapangan yang dilakukan oleh peneliti.

Perubahan pola pemukiman yang terjadi pada masyarakat Bajo tidak terlepas dari kebijakan pemerintah setempat. Pemerintah sebagai pengusul perpindahan tersebut menyediakan lokasi yang tidak jauh dari wilayah pantai, alasan dari pemilihan tempat ini dikarenakan untuk lebih memudahkan masyarakat dalam kegiatan sehari-hari dan pengembangan wilayah administratif. Pemilihan lokasi dekat pantai rupanya berdampak pada pola pemukiman masyarakat, karena pada saat masyarakat mulai membangun rumah tidak lagi saling membelakangi sebagaimana tempat mereka dahulu ketika masih tinggal di Pulau Masudu tetapi telah berubah yaitu berjejer dengan saling berhadapan dengan pola membujur dari arah utara dan selatan yang menyusuri pesisir dan melengkung membentuk huruf L. Menurut penuturan informan bahwa " perpindahan masyarakat Bajo ke wilayah Desa Liano tidak terlepas dari peran serta pemerintah yang merasa prihatin dengan keadaan mereka sewaktu masih tinggal di Pulau Masudu, disamping itu masyarakat telah disiapkan satu lokasi sebagai tempat pemukiman" (Syarifuddin, wawancara, 23 Juni 2015).

Menurut penuturan informan iagi bahwa Pola pemukiman masyarakat Bajo di Desa Liano berubah drastis yang semula rumah mereka adalah rumah panggung dengan berdindingkan daun kelapa dan daun sagu (rumbia) serta berlantaikan bambu dan papan sekarang berubah menjadi rumah permanen dan semi permanen seperti bentuknya rumah panggung yang beratapkan seng dan sebagian rumbia dan berdindingkan tembok dan sebagian lagi menggunakan papan (Alwan, wawancara 23 Juni 2015).

Pemukiman masyarakat Bajo yang ada di Desa Liano sudah dilengkapi dengan 
fasilitas pemerintahan, keagamaan, adanya perkembangan dalam kehidupan pendidikan, kesehatan dan transportasi yang mereka hal ini didapatkan dari hasil sangat membantu masyarakat dalam wawancara bersama Myusuf "setelah menjalankan kehidupan sehari-hari. Kondisi masyarakat Bajo pindah di pemukiman baru ini sangatlah kontras dengan kehidupan awal ini masyarakat Bajo merasakan adanya mereka di Pulau Masudu yang sangat minim perubahan dalam kehidupan, hal ini karena akan fasilitas. Penyediaan fasilitas tersebut adanya sarana dan prasarana yang disediakan sepenuhnya diperuntukkan untuk mencapai oleh pemerintah" (Myusuf Wawancara, 23 pemerataan penyelenggaraan pemerintahan Juni 2015).

dan mencapai kesejahteraan bersama.

Kegiatan keagamaan pada masyarakat

Saat ini mayoritas rumah yang ada di lingkungan Bajo Desa Liano berbentuk permanen dan sebagian lagi semi permanen. Bagi masyarakat yang bentuk rumahnya masih semi permanen biasanya mendapatkan bantuan dari pemerintah berupa semen, papan, dan seng. Pemanfaatan pekarangan disetiap rumah-rumah yang ada di lingkungan Bajo di Desa Liano saat ini lebih didominasi oleh warung-warung dan kioskios yang merupakan pekerjaan sampingan mereka. Bagi anak-anak Bajo yang telah menikah ada yang tetap memilih tinggal di lingkungan Bajo di Desa Liano dan ada juga yang mencari tempat diluar lingkungan/Desa mereka. Hal ini dilatar belakangi inisiatif untuk hidup lebih baik sebagaimana yang terjadi di masyarakat Bajo lainnya.

Tersedianya sarana pendidikan, Bajo saat ini difokuskan pada sebuah mesjid yang menjadi pusat kegiatan keagamaan bagi masyarakat yang bermukim di Desa Liano. Lokasi mesjid yang mudah berada ditengah pemukiman menjadikan mesjid ini sebagai tempat ibadah dan sarana bagi masyarakat Bajo untuk bercengkrama dengan masyarakat lain. Mesjid ini merupakan mesjid pertama yang ada di Desa Liano sehingga mesjid ini menjadi ramai akan hadirnya masyarakat Bajo, baik ketika kegiatan keagamaan seperti shalat tarawi, shalat Jumal, maupun shalat Shubuh, shalat Magrib dan Isya.

Kehidupan Sosial Ekonomi Masyarakat Bajo

Masyarakat dalam kehidupannya pasti mengalami perkembangan dengan kata lain tidak ada masyarakat yang statis. Semua kesehatan, keagamaan dan sarana masyarakat berubah menurut kadar pemerintahan di pemukiman baru telah perubahannya masing-masing ada yang membawa perubahan-perubahan dalam berubah dengan cepat, ada juga berubah kehidupan masyarakat Bajo. Saat ini dengan lambat, bahkan ada juga yang tidak setidaknya masyarakat Bajo telah merasakan kelihatan perubahannya. Perkembangan 
dalam masyarakat bisa terjadi karena faktorfaktor yang datang dalam diri masyarakat maupun dari luar masyarakat.

Untuk dapat mengetahui suatu masyarakat mengalami perubahan maka harus melihat bagaimana masyarakat tersebut pada masa lampau kemudian membandingkannya dengan keadaan saat ini, dengan cara yang demikian maka kita akan mengetahui masyarakat tersebut mengalami perubahan atau tidak mengalami perubahan.

Perpindahan masyarakat yang difasilitasi oleh pemerintah secara perlahanlahan membawa perubahan-perubahan dalam masyarakat Bajo di Desa Liano yang tidak terlepas dari peran serta pemerintah setempat sebagai lembaga tertinggi rupanya memiliki perhatian yang cukup besar terhadap keberadaan masyarakat Bajo di lingkungan baru mereka. Selain memilihkan lokasi pemukiman yang dekat dengan jalan agar memudahkan masyarakat dalam melakukan kehidupannya, juga menyediakan saranasarana yang membawa pada perubahan masyarakat.

Kehidupan sosial ekonomi masyarakat Bajo cenderung bergerak menuju ke arah konsepsi dan nilai-nilai budaya yang dianut oleh kelompok masyarakat bagai, khususnya masyarakat Bugis. Hal ini disebabkan oleh beberapa faktor antara lain yaitu: (a) ikatan geneologis yaitu adanya asal usul yang sama dengan orang Bugis; (b) orientasi ekonomi yaitu ketergantungannya terhadap orang Bugis; (c) keunggulan komparatif yaitu keunggulan-keunggulan yang dimiiiki oleh orang Bugis terhadap orang Bajo, dan (d) status sosial yakni keinginan masyarakat Bajo "tampil" seperti masyarakat Bugis.

Tentunya faktor-faktor tersebut tidak berdiri sendiri tetapi saling terkait satu sama lain dan muncul berdasarkan adaptasi masing-masing kelompok pelaku perubahan (pendukung kebudayaan). Faktor-faktor ini juga muncul berdasarkan kebutuhan dari masing-masing kelompok pelaku perubahan dalam interaksinya dengan orang hagai, khususnya orang Bugis.

Munculnya konsep sama dan hagai pada masyarakat Bajo telah melahirkan pola interaksi yang berbeda secara kultural antara kelompok masyarakat Bajo dengan masyarakat bukan Bajo yang cenderung bersifat segregatif khususnya dalam hal okupasi dan pemukiman. Kelompok masyarakat Bajo dan kelompok masyarakat Bugis, memiliki asal usul yang sama (geneologis). Sesuai mitos yang berkembang, masyarakat Bajo di Desa Liano meyakini asal usulnya dari Ussu-Cerekang, Kabupaten Luwu, Sulawesi Selatan (Nurung, Wawancara, 9 Juli 2015). Hal inilah yang menjadi salah satu faktor yang mendasari perubahan makna sama dan hagai Orang Bugis di mata orang Bajo di Desa Liano dianggap saudara. 
Kelompok masyarakat Bajo dengan pola budayanya di laut selama berabad-abad, tidak banyak menyerap unsur-unsur budaya dari kelompok masyarakat pendukung kebudayaan lain, sebaliknya kelompok masyarakat Bugis yang hidup di darat dan juga memiliki semangat kebaharian telah mengalami berbagai macam interaksi dengan kelompok lain sehingga telah menyerap berbagai macam nilai-nilai baru.

Dalam kondisi perkembangan budaya seperti ini masyarakat Bajo tetap mempertahankan kecenderungannya untuk selektif berinteraksi dengan kelompok masyarakat luar (bagai) dengan mengembangkan konsep budaya olai lesse (menghindari konflik). Karena itu kelompok masyarakat ini tetap menjadi kelompok masyarakat yang senantiasa "mengisolir diri" sehingga dalam memilih tempat pemukiman tetap bersifat segregatif. Adanya kepercayaan bahwa laut adalah milik kelompoknya (samadapu'madi lao') menyebabkan pilihan pekerjaan hanya sebagai nelayan, sementara itu kelompok masyarakat bagai telah mengembangkan berbagai macam diversifikasi pekerjaan, termasuk orang Bugis.

Sejarah perjalanan kehidupan orang Bajo menunjukkan adanya kontak dagang yang telah berlangsung lama dengan orang Bugis. Pada awalnya, kontak dagang hanya terjadi di tengah laut dengan sistem selo (barter) antara orang Bajo dengan orang
Bugis. Pada perkembangan selanjutnya, kehadiran orang Bugis yang bermukim di pesisir pantai sangat dibutuhkan oleh orang Bajo untuk memenuhi segala kebutuhannya, baik sandang, pangan maupun pemenuhan alat- alat produksi penangkapan ikan. Bahkan intensitas pertemuannya tidak hanya terjadi di tengah laut atau di pantai dalam kaitannya dengan distribusi hasil tangkapannya, tetapi orang Bajo telah menjangkau aktivitas perdagangan di pasar, baik untuk kepentingan menjual hasil tangkapannya maupun untuk memenuhi berbagai kebutuhannya.

Sementara itu, aktivitas perdagangan dipasar-pasar tradisional di Desa Liano pada umumnya dilakukan oleh orang-orang Bugis, dan sebagian orang Bajo khususnya di pasar ikan. Begitu pula dalam pengadaan alat-alat produksi, khususnya dalam pembuatan perahu (lepa-Iepa) maupun perahu bermesin (katinting). Masyarakat Bajo telah menjalin kerjasama dengan panrita lopi (pembuat perahu). Profesi sebagai panrita lopi kebanyakan ditekuni oleh masyarakat Bugis. Ketergantungan masyarakat Bajo terhadap masyarakat Bugis dalam memenuhi kebutuhan hidupnya seperti, hasil perkebunan dan bahan-bahan sembako, masih nampak terhadap kehidupan masyarakat Bajo di Desa Liano. Hal ini menunjukan bahwa masyarakat Bajo dengan masyarakat Bugis masih menjalin kerja sama dalam memenuhi kebutuhan hidupnya. 
Mereka tidak dapat menghindar dari kenyataan ini, sehingga satu-satunya jalan adalah mengadaptasikan pola-pola budayanya terhadap kebudayaan Bugis.

Kehidupan sosial Masyarakat Bajo di Desa Liano lambat-laun dapat menyesuaikan diri dengan masyarakat lain yang ada disekelilingnya. Didalam menjalani kehidupan sehari-harinya, masyarakat Bajo mampu berinteraksi terhadap masyarakat Bugis dengan baik. Terjadinya interaksi yang mahasiswa, Pegawai Negeri Sipil (PNS), dan baik antara masyarakat Bajo dengan Politisi. (Myusuf, Wawancara, 9 Juli 2015)

perkawinan dengan masyarakat Bugis, maupun yang menikah dengan sesama masyarakat Bajo. lama-kelamaan sebagian, profesi pekerjaannya pun dapat berubah seperti menjual makanan ringan dan bahanbahan sembako, berkebun, pengusaha sukses, bahkan sebagian ada berprofesi sebagai

Tabel 5. Keadaan Pekerjaan Penduduk masyarakat Bajo di Desa Liano

\begin{tabular}{|c|c|c|c|}
\hline \multirow{3}{*}{ Profesi pekerjaan } & \multirow{2}{*}{\multicolumn{2}{|c|}{ Jenis Kelamin }} & \multirow{3}{*}{$\begin{array}{c}\text { Jumlah } \\
\text { (Jiwa) }\end{array}$} \\
\hline & & & \\
\hline & Laki-Laki & Perempuan & \\
\hline Nelayan & 400 & 17 & 417 \\
\hline Montir & 2 & - & 2 \\
\hline Petani & 4 & - & 4 \\
\hline Pengusaha kecil dan menengah & 6 & - & 6 \\
\hline Mahasiswa & 2 & 2 & 4 \\
\hline Pelayar & 1 & - & 1 \\
\hline PNS & 2 & 1 & 3 \\
\hline TNI & 1 & - & 1 \\
\hline Dukun kampung terlatih & 2 & - & 2 \\
\hline Total & 420 & 20 & 440 \\
\hline
\end{tabular}

Sumber: Kantor Desa Liano 2015 n 
menunjukkan suatu pola tertentu seperti square, rectangle, circle, atau oval. Setiap pola ini bukan hanya menunjukkan tatanan saja, akan tetapi juga memiliki rangka struktur pembentuk ruang dan di dalamnya mengandung makna centers dan axes.

\section{PENUTUP}

Berdasarkan hasil penelitian yang dikemukakan pada pembahasan di atas, maka peneliti dapat mengambil simpulan yaitu:

1. Latar belakang perpindahan masyarakat Bajo dari Pulau Masudu ke Pesisir Pantai Desa Liano adalah: faktor geografi, faktor kebijakan pemerintah, faktor ekonomi.

2. Proses perpindahan masyarakat Bajo dilakukan secara bertahap yang diawali masyarakat yang tinggal di bagian Barat Pulau Masudu pada tahun 1999, dengan menyeberangi laut dan sebagian masyarakat membawa perkakas rumah yang ada di Pulau Masudu.
3. Pola pemukiman ini disebabkan ketika berpindah masyarakat membangun rumah mengikuti jalan yang telah disediakan sebelumnya. Pola pemukiman dilingkungan baru ini sangat berbeda dengan pemukiman di Pulau Masudu, dimana saat bermukim di Pulau Masudu masyarakat membentuk pemukiman secara terpencar dan saling membelakang hal ini disebabkan oleh kondisi geografis, setelah di pesisir pantai mengikuti pola linear.

4. Kehidupan sosial ekonomi masyarakat Bajo adalah terciptanya interaksi dengan masyarakat lain yang ada di darat serta tersedianya prasarana bagi masyarakat Bajo sehingga mempermudah mereka dalam berbagai aktivitas.

\section{DAFTAR PUSTAKA}

Ari, Dwi. I. R., Antariksa. 2005. Studi Karakteristik Pola Permukiman di Kecamatan Labang, Madura. Jumal ASPI Volume 4 Nomor 2, April 2005, him. 78-93.

Arif Sulaiman, dkk. 1987. Migrasi Penduduk Sulawesi Selatan di Kendari. Laporan Hasil Penelitian. Kendari: Lembaga Penelitian Unhalu.

Bintarto. 1997. Kemiskinan di Perkotaan. Jakarta: Sinar Harapan.

Blaang. 1986. Ekologi Lingkungan. Surabaya: Sinar Harapan.

Budihardjo, Eko.1984. Sejumlah Masalah Pemukiman Kota. Bandung: Alumni.

Bahtiar. 2011. Transisi Kebudayaan Suku Bajo. Kendari: HISPISI.

Chapin, P. Stuart. 1979. Urban Land Use Planning. Chicago: University of Illimois Press. 
Dian, dkk. 2008. Perkembangan Pemukiman dan Tipologi Rumah Tinggal pada Perumahan Karyawan Pabrik Gula Pesantren Barn Kediri. Jurnal Arsitektur Volume 1 Nomor 1, Maret 2008 Fakultas Teknik Universitas Brawijaya Malang.

Haryanto, Dani Dkk. 2011. Pengantar Sosiologi Dasar. Jakarta: PT Prestasi Pustakarya. Hassan, Shadilly. 1993. Sosiologi Untuk Masyarakat Indonesia. Jakarta: PT Rineka Cipta.

Jayadinata, Johara T. 1999. Tata Gurta Tanah dalam Perencanaan Pedesaan, Perkotaan, dan Wilayah. Bandung: ITB.

Jumardi, 2014. Dari Laut Ke Darat: Pola Pemukiman Masyarakat Bajo di Kelurahan Boepinang Kecamatan Poleang Kabupaten Bombana. Skripsi Unhalu. Kendari.

Jarmasi, 1996. Migrasi Orang Bajo ke Desa Waitii Kecamatan Tomia (Tinjauan Sejarah). Skripsi Unhalu. Kendari.

Sujono. 1965. Ilmu Masyarakat Umum Pengantar Sosiologi Dasar. Jakarta: PT Prestasi Pustakarya.

Soekanto, Soeijono. 1990. Sosiologi Suatu Pengantar. Jakarta: Rajawali Press.

Sunarto, Kumanto. 2004. Pengantar Sosiologi. Jakarta: Penerbit Lembaga Fakultas Ekonomi Universitas Indonesia.

Sjamsudin, Helius. 1998. Metodologi Sejarah. Jakarta: Depdikbud.

Kasianto. 2006. Pedoman Pemdisan Sejarah Lokal. Jakarta: Departemen Kebudayaan dan Pariwisata.

La Ode Muharam. 1993. Pola Hidup dan Sikap Mental Masyarakat Bajo di Sulawesi Tenggara. Lembaga Penelitian Unhalu: Kendari.

Nasruddin, Suyuti. 2004. Bajo dan Bukan Bajo, Studi Tentang Perubahan Makna Sama dan Bagai. Pada Masyarakat Bajo di Desa Sulaho Kabupaten Kolaka Sulawesi Tenggara.

Nugroho Notosusanto. 1978. Masalah Penelitian Sejarah Kontenporer (Suatu Pengalaman). Jakarta: Yayasan Idayu.

Mutakin, dkk. 2004. Dinamika Masyarakat Indonesia. Bandung: Genesindo.

Melamba, Basrin. 2011. Kota Pelabuhan Kolaka di Teluk Bone 1906-1942. Bali: Pustaka Larasan.

Mulyati, Ahda. 1995. Pola Spasial Pemukiman di Kampung Kauman, YogyakartalYesis. Tidak Diterbitkan. Yogyakarta: Program Pasca Sarjana, UGM.

Mohammad Noor Syam. 1984. Filsafat Pendidikan dan Dasar Filsafat pendidikan Pancasila. Surabaya: Penerbit Usaha Nasional.

Ngadiono. 1984. Kelembagaan dan Masyarakat. Jakarta: Bina Aksara.

Sasongko, I. 2002. Transformasi Struktur Ruang pada Pemukiman Sasak, Kasus: Pemukiman Tradisional Desa Payung. Jurnal ASPI.

Poedarminta. 1986. Kamus Umum Bahasa Indonesia. Balai Pustaka: Jakarta.

Uka Tjandra Sasmita. 1985. Kota Pemukiman Masa Pertumbuhan Kerajaan- Kerajaan Pengaruh Islam di Indonesia. Jakarta: PIA III.

Undang-Undang Nomor 4 tahun 1992. Tentang Perumahan dan Permukiman. Jakarta: Sekretariat Negara RI.

Undang-Undang Republik Indonesia Nomor 1 Tahun 2011. Tentang Perumahan dan Kawasan Permukiman.

Vincent, 1995.Pola spatial permukiman kampung Kauman Yogyakarta, Tesis Program pasca sarjana UGM, Yogyakarta.

Wiriadtmadja, S. 1981. Pokok-Pokok Sosiologi Pedesaan. Jakarta: CV. Tasagun. 